\title{
EVALUATION OF PRENATAL CARE AT BASIC HEALTH UNITS IN THE CITY OF SAO PAULO
}

\author{
Regina Célia de Menezes Succi ${ }^{1}$ \\ Elisabeth Niglio Figueiredo ${ }^{1}$ \\ Letícia de Carvalho Zanatta \\ Marina Biffani Peixe ${ }^{2}$ \\ Marina Bertelli Rossi ${ }^{2}$ \\ Lucila Amaral Carneiro Vianna ${ }^{3}$
}

Succi RCM, Figueiredo EN, Zanatta LC, Peixe MB, Rossi MB, Vianna LAC. Evaluation of prenatal care at basic health units in the city of São Paulo. Rev Latino-am Enfermagem 2008 novembro-dezembro; 16(6):986-992.

The aim of this study was to evaluate the quality of prenatal care offered in 12 Basic Health Units (BHU) in the city of Sao Paulo, Brazil, through a review of medical and nurse charts, before and after the municipalization of the public health system. The indicator used considered excellence in care as: starting prenatal care in the first quarter of pregnancy; at least six medical visits; at least two results of blood screening for syphilis and one for HIV; returning to BHU up to 42 days after delivery. This indicator was not present in any care delivered in 2000, and only $7.7 \%$ of the care delivered in 2004 obtained it (1.1\% to 30\% of the care per unit assessed). Although there was an evident improvement in care during the period, the low proportion of excellent prenatal care shows an urgent need to improve this care in the BHU of São Paulo city.

DESCRIPTORS: prenatal care; quality of health care; syphilis, congenital; HIV

\section{EVALUACIÓN DE LA ASISTENCIA PRENATAL EN UNIDADES BÁSICAS DEL MUNICIPIO DE SAN PABLO}

El objetivo de este estudio fue evaluar la calidad de la asistencia prenatal ofrecida en doce Unidades Básicas de Salud (UBS) del municipio de San Pablo a través de la revisión de los registros médicos y de enfermería antes y después de la municipalización del sistema de salud. Fue utilizado un indicador que consideraba como atención de excelencia aquella con: inicio del acompañamiento prenatal en el primer trimestre de la gestación; con un mínimo de seis consultas; registro de por lo menos dos resultados de exámenes serológicos para sífilis y una prueba para el VIH; retorno a la UBS hasta 42 días después del parto. Ese indicador no fue obtenido en ninguna atención realizada en el 2000 y apenas en 7,7\% de las atenciones en el 2004 (1,1\% a 30\% de las atenciones por unidad evaluada). A pesar de que con evidente mejoría de la atención en el período, la baja proporción de atención prenatal de excelencia, revela una urgente necesidad de mejorar esa asistencia en las UBS en el Municipio de San Pablo.

DESCRIPTORES: atención prenatal; calidad de atención de salud; sífilis congénita; VIH

\section{AVALIAÇÃO DA ASSISTÊNCIA PRÉ-NATAL EM UNIDADES BÁSICAS DO MUNICÍPIO DE SÃO PAULO}

O objetivo deste estudo foi avaliar a qualidade da assistência pré-natal oferecida em doze Unidades Básicas de Saúde (UBS) do município de São Paulo, através da revisão dos prontuários médicos e de enfermagem antes e após a municipalização do sistema de saúde. Foi utilizado um indicador que considerava como atendimento de excelência aquele com início do acompanhamento pré-natal no primeiro trimestre da gestação, no mínimo seis consultas, registro de pelo menos dois resultados de exames sorológicos para sífilis e um teste para o HIV, retorno à UBS até 42 dias pós-parto. Esse indicador não foi obtido em nenhum atendimento realizado em 2000 e apenas em 7,7\% dos atendimentos em 2004 (1,1 a 30\% dos atendimentos por unidade avaliada). Embora com evidente melhora do atendimento no período, a baixa proporção de atendimento pré-natal de excelência revela urgente necessidade de melhorar essa assistência nas UBS no Município de São Paulo.

DESCRITORES: cuidado pré-natal; qualidade da assistência à saúde; sífilis congênita; HIV

Federal University of São Paulo, Brazil:

${ }^{1}$ Adjunct Professor, e-mail: succi@picture.com.br, elisabeth@denf.epm.br; ${ }^{2}$ Nursing undergraduate student, e-mail: marinapeixe@itelefonica.com.br; ${ }^{3}$ Full Professor, e-mail: Ivianna@reitoria.epm.br. 


\section{INTRODUCTION}

Prenatal care is defined as the set of clinical and education procedures to follow-up pregnancy evolvement and to promote the health of pregnant women and their infants. To assess the quality of this care with a view to its improvement demands constant efforts from health authorities, professionals performing these actions as well as from the target population, which should be aware of possible problems and seek help.

In Brazil, epidemiological surveillance has managed to appoint problems; however, it has not been able to enhance the feasibility of prevention measures $^{(1)}$. The program Humanização no Pré-natal e Nascimento (Prenatal and Birth Humanization Program-PHPN), created by the Ministry of Health in $2000^{(2)}$, defined minimal procedures for suitable care and established a computerized control system (SisPreNatal) for proper follow-up of pregnant women registered in the PHNP, which is part of the Single Health System (SUS). The program registers pregnant women upon their first visit and follows them until the puerperal pregnancy. Municipalization of health services is part of a process of political, technical, and administrative decentralization, translated into the introduction, organization, and management of resources - in São Paulo, this process started in 2001.

An assessment of prenatal care quality and the problems resulting in newborns with congenital syphilis in 41 Basic Health Units (BHU) in the city of São Paulo(3) in 2000 concluded, among other points, that the care delivered to pregnant women in most units under study does not meet the Ministry of Health requirements ${ }^{(4)}$. The creation of quality indicators in this survey enabled us to identify problems, to assess the introduction of public policies in health, to organize services to monitor preventive actions in prenatal care, and to attempt to eradicate and/or control the possible adverse outcomes for pregnant women and their children $^{(3)}$.

The objective of the present study was to assess, using quality indicators, the quality of prenatal care offered in basic health units of the city of São Paulo, comparing distinct periods: 2000 (before) and 2004 (four years after the municipalization of health services).

\section{MATERIALS AND METHODS}

This is a descriptive cross-sectional epidemiological study, assessing charts of pregnant women. In the present study, we used a sample of 12 $\mathrm{BHU}$, randomly chosen among the $41 \mathrm{BHUs}$ that were part of our previous study ${ }^{(2)}$ performed in 2000, that is, immediately before the municipalization of health services in the city of São Paulo.

Management models of the $12 \mathrm{BHU}$ assessed in 2004 were the same as in the year 2000 (traditional $\mathrm{BHU}$; mixed units with traditional care model + family health program; units presenting only family health program) except for one unit that went from a traditional $\mathrm{BHU}$ in 2000 to a mixed one in 2004. Five units were subject to the health coordination of Eastern São Paulo, four from the North region, two from the South and one from the Center.

All charts of pregnant women performing prenatal visits at each BHU in 2004 were assessed (even if follow-up had started in 2003 or finished in 2005). Elegibility criteria were met by 1299 pregnant women. This study investigated chart variables related with the pregnant women, the prenatal data and newborns.

Based on the guidelines by the Ministry of Health $^{(4)}$, the following was considered as adequate prenatal care: beginning of follow-up in the first quarter of pregnancy; at least six visits; record of at least two screenings for syphilis (VDRL); record of screening for Human Immunodeficiency Virus - HIV; returning to the $\mathrm{BHU}$ up to 42 days after delivery. An index was built, using the relationship between the number of pregnant women whose prenatal followup at the unit met all these items (adequate or excellent prenatal care) and the total number of pregnant women seen in the period. All data available in the charts were used: medical and nursing notes, and results of laboratory exams (taken from medical charts and in the records of the SisPreNatal system).

After collection, selected variables were summarized as figures and percentages for qualitative variables and as mean \pm standard deviation for quantitative variables. Comparisons between the two years of the study were made in each of the units assessed, using Chi-Square or Fisher's exact test for qualitative variables and Student's t test for quantitative variables.

This survey was funded by CNPq (National Council for Scientific and Technological Development) (public notice 036/2004), and approved by the Research Ethics Committee of the Federal University of São Paulo and the Health Secretariat of the city of São Paulo. 


\section{RESULTS}

Patients in prenatal follow-up at the 12 units (identified by numbers 1 to 12 ) totaled 818 pregnant women in 2000 and 1299 women in 2004, ranging from 41 to 147 pregnant women/BHU in 2000 and 40 to 299 pregnant women/BHU in 2004. The number of prenatal medical visits in 2004 was higher than in 2000 at all BHU but one. The care model at the units assessed was the following: seven Basic Health Units $(\mathrm{BHU})$, four mixed units (BHU + Family Health Program - PSF), and one with FHP-type care.

The mean and standard deviation of the number of medical visits per pregnant woman at the units ranged from $4.6 \pm 1.9$ to $6.8 \pm 3.2$ in 2000 and from $3.9 \pm 1.8$ to $6.5 \pm 3.2$ in 2004 . Comparing the two years studied, these means were different (with statistical significance) in only three units: in units 2 and 6 , there was a decrease in the number of medical visits (6.1 2.1 to $4.9 \pm 2.0$ and $6.8 \pm 3.2$ to $4.7 \pm 2.7$; Student's t test, $\mathrm{p}=0.007$ and $\mathrm{p}<0.001$ respectively) and, in unit 9, there was an increase in the number of medical visits $(4.8 \pm 2.3$ to $5.5 \pm 1.8$; Student's t test, $p=0.048)$. Marginally significant differences in the mean number of visits were observed with decrease in one unit and increase in three.

The proportion of pregnant women going to nursing visits was small at all $\mathrm{BHU}$, ranging from $0.70 \%$ to $28.20 \%$. The total number of visits performed, adding up medical and nursing visits, is shown in Table 1.

Table 1 - Distribution of the number of pregnant women with total number of visits (physicians/nurses) higher than or equal to 6 according to the Health Unit and year

\begin{tabular}{cccc}
\hline Health Unit & \multicolumn{2}{c}{ Year } & \\
& $\mathbf{2 0 0 0}$ & $\mathbf{2 0 0 4}$ & p-valor ${ }^{\#}$ \\
\hline 1 & $23(52.30 \%)$ & $48(57.10 \%)$ & 0.599 \\
2 & $22(55 \%)$ & $24(43.60 \%)$ & 0.274 \\
3 & $25(37.90 \%)$ & $48(61.50 \%)$ & 0.005 \\
4 & $24(39.30 \%)$ & $80(56.30 \%)$ & 0.026 \\
5 & $26(39.40 \%)$ & $56(60.90 \%)$ & 0.008 \\
6 & $35(68.60 \%)$ & $39(73.60 \%)$ & 0.577 \\
7 & $54(36.70 \%)$ & $96(32.20 \%)$ & 0.343 \\
8 & $28(52.80 \%)$ & $31(77.50 \%)$ & 0.014 \\
9 & $27(39.10 \%)$ & $42(48.30 \%)$ & 0.253 \\
10 & $39(58.20 \%)$ & $61(62.20 \%)$ & 0.602 \\
11 & $49(48.50 \%)$ & $102(63.80 \%)$ & 0.015 \\
12 & $18(36 \%)$ & $58(53.20 \%)$ & 0.044 \\
\hline
\end{tabular}

${ }^{*}$ Chi-Square
Pre-natal follow-up was started in the first trimester of the pregnancy for $459 / 818$ pregnant women (56.10\%) in 2000, ranging from $39.60 \%$ to $85.00 \%$ at the $12 \mathrm{BHU}$ studied (Table 2); in 2004, this ratio ranged from $37.20 \%$ to $80.80 \%$. In total, there was a significant increase in the number of pregnant women who started prenatal care in the first trimester of pregnancy from 2000 to 2004 (Chi-square, $\mathrm{p}<0.05)$, although this ratio was lower in five of the 12 units studied.

Table 2 -Distribution of the number of pregnant women that started prenatal in the first trimester of pregnancy according to Year and Health Unit

\begin{tabular}{cccc}
\hline & \multicolumn{2}{c}{ Year } & \\
Health Unit & $\mathbf{2 0 0 0}$ & $\mathbf{2 0 0 4}$ & p-valor \# \\
\hline 1 & $27(61.40 \%)$ & $51(62.20 \%)$ & 0.927 \\
2 & $34(85 \%)$ & $35(67.30 \%)$ & 0.052 \\
3 & $38(57.60 \%)$ & $63(80.80 \%)$ & 0.002 \\
4 & $34(55.70 \%)$ & $101(72.70 \%)$ & 0.019 \\
5 & $41(62.10 \%)$ & $47(51.60 \%)$ & 0.192 \\
6 & $36(70.60 \%)$ & $42(79.20 \%)$ & 0.308 \\
7 & $77(52.40 \%)$ & $153(52 \%)$ & 0.946 \\
8 & $21(39.60 \%)$ & $32(80 \%)$ & $<0.001$ \\
9 & $34(49.30 \%)$ & $47(56 \%)$ & 0.410 \\
10 & $35(52.20 \%)$ & $35(37.20 \%)$ & 0.058 \\
11 & $53(52.50 \%)$ & $125(78.60 \%)$ & $<0.001$ \\
12 & $29(58 \%)$ & $52(48.60 \%)$ & 0.272 \\
\hline & & & \\
\hline & & &
\end{tabular}

\# Chi-square

The ratio of pregnant women performing follow-up until the third trimester of pregnancy decreased in the study period: from 711/818 (86.90\%) in 2000 to $962 / 1299$ (74.00\%) in 2004. Three units presented a significant decrease in this ratio and only two presented an increase. However, this difference was not statistically significant.

At least, one blood test for syphilis was performed during prenatal care in $76.70 \%$ (628/818) of the pregnant women followed in 2000, and in $86.00 \%(1117 / 1288)$ in 2004. Table 3 presents health units according to the number of VDRL screenings performed during prenatal follow-up in the two years assessed. 
Table 3 - Distribution of health units according to number of pregnant women performing two VDRL screenings or more, City of São Paulo, 2000/2004

\begin{tabular}{|c|c|c|c|c|c|c|c|}
\hline \multirow[t]{2}{*}{ Health Unit } & \multicolumn{3}{|c|}{ Number of VDRL in the year 2000} & \multicolumn{3}{|c|}{ Number of VDRL in the year 2004} & \multirow[b]{2}{*}{ p-value \# } \\
\hline & Zero & One & Two or over & Zero & One & Two or over & \\
\hline 1 & - & $21(95.50 \%)$ & $1(4.50 \%)$ & - & $12(30.80 \%)$ & $27(69.20 \%)$ & $<0.001$ \\
\hline 2 & $10(24.40 \%)$ & $31(75.60 \%)$ & - & - & $38(100 \%)$ & - & 0.001 \\
\hline 3 & $28(42.40 \%)$ & $38(57.60 \%)$ & - & - & $65(91.50 \%)$ & $6(8.50 \%)$ & 0.007 \\
\hline 4 & $10(16.40 \%)$ & $34(55.70 \%)$ & $17(27.90 \%)$ & & $42(36.50 \%)$ & $73(63.50 \%)$ & $<0.001$ \\
\hline 5 & $19(28.80 \%)$ & $44(66.70 \%)$ & $3(4.50 \%)$ & - & $80(96.40 \%)$ & $3(3.60 \%)$ & $<0.001$ \\
\hline 6 & $3(6 \%)$ & 42 (84\%) & $5(10 \%)$ & - & $35(77.80 \%)$ & $10(22.20 \%)$ & 0.074 \\
\hline 7 & $21(14.30 \%)$ & $121(82.30 \%)$ & $5(3.40 \%)$ & - & $43(76.80 \%)$ & $13(23.20 \%)$ & $<0.001$ \\
\hline 8 & $10(18.05 \%)$ & $42(77.80 \%)$ & $2(3.70 \%)$ & - & $10(38.50 \%)$ & $16(61.50 \%)$ & $<0.001$ \\
\hline 9 & $14(20.30 \%)$ & 46 (66.70\%) & $9(13 \%)$ & - & 33 (38.80\%) & 52 (61.20\%) & $<0.001$ \\
\hline 10 & $22(33.80 \%)$ & 33 (50.80\%) & $10(15.40 \%)$ & - & $36(41.40 \%)$ & $51(58.60 \%)$ & $<0.001$ \\
\hline 11 & $25(25 \%)$ & $50(50 \%)$ & $25(25 \%)$ & $23(17,20 \%)$ & 71 (53\%) & $40(29.90 \%)$ & 0.317 \\
\hline 12 & - & $23(100 \%)$ & - & - & $52(55.30 \%)$ & $42(44.70 \%)$ & $<0.001$ \\
\hline
\end{tabular}

"Student's t test.

Performance of at least one blood test for syphilis in $100 \%$ of the pregnant women seen was obtained in only 2 units in 2000 and in 11/12 (92\%) in 2004. The ratio of pregnant women performing the two screenings recommended ranged from zero to $25 \%$ in 2000 and from $3.60 \%$ to $69.20 \%$ in 2004 . The ratio of pregnant women undergoing a blood test for syphilis increased significantly at 5 units, although only $2 \mathrm{BHU}$ performed at least one test in all pregnant women seen in the two periods. One unit still presented, in 2004, $17.20 \%$ of prenatal charts with no records for syphilis screening.

Prevalence of HIV-infected pregnant women was $3.70 \%$ in 2000 , decreasing to $0.60 \%$ in 2004 . There was an increase in the ratio of HIV blood tests performed from 2000 (510/818) to 2004 (1096/1299); this difference was statistically significant in five units $(p<0.05)$. In 2004 , more than $80.0 \%$ of pregnant women seen in all units performed this test. Distribution of pregnant women undergoing HIV blood test in the health units studied is shown in Table 4.

Table 4 - Distribution of the number of pregnant women undergoing blood test for HIV per health unit, City of São Paulo, 2000/2004

\begin{tabular}{cccc}
\hline \multirow{3}{*}{ Health Unit } & $\mathbf{2 0 0 0}$ & $\mathbf{2 0 0 4}$ & p-value $^{*}$ \\
\hline 1 & $22(53.70 \%)$ & $75(94.90 \%)$ & $<0.001$ \\
2 & $34(100 \%)$ & $41(95.30 \%)$ & 0.500 \\
3 & $39(68.40 \%)$ & $74(94.90 \%)$ & $<0.001$ \\
4 & $45(100 \%)$ & $129(99.20 \%)$ & $>0.999$ \\
5 & $43(81.10 \%)$ & $85(97.70 \%)$ & 0.001 \\
6 & $45(93.80 \%)$ & $43(91.50 \%)$ & 0.714 \\
7 & $114(86.40 \%)$ & $224(84.80 \%)$ & 0.688 \\
8 & $44(93.60 \%)$ & $38(97.40 \%)$ & 0.623 \\
9 & $54(100 \%)$ & $85(98.80 \%)$ & $>0.999$ \\
10 & $2(3.40 \%)$ & $85(95.50 \%)$ & $<0.001$ \\
11 & $67(100 \%)$ & $120(100 \%)$ & - \\
12 & $1(4.20 \%)$ & $97(100 \%)$ & $<0.001$ \\
\hline${ }^{*}$ Chi-square & & &
\end{tabular}

In the assessment conducted in 2000, none of the 818 pregnant women followed returned to the $\mathrm{BHU}$ in the first 42 days after delivery. In 2004, 1239 pregnant women had a record of this information in their medical charts, and 481 of them (38.80\%) returned to the $\mathrm{BHU}$ within this period, however, in only $4 \mathrm{BHU}$, over $50 \%$ of the pregnant women were assessed in the puerperal period.

The excellence indicator was achieved by only 100 of the 1299 pregnant women assessed in 2004 $(7.70 \%)$ (Table 5). In 2000, this indicator was not obtained because they did not return to the BHU within 42 days after delivery.

Table 5 - Number of pregnant women presenting the excellence indicator in prenatal care in 2004 according to the Health Unit

\begin{tabular}{|c|c|c|c|}
\hline Health Unit & $\begin{array}{l}\text { \# of pregnant } \\
\text { women with } \\
\text { indicator }\end{array}$ & $\begin{array}{c}\text { Total number } \\
\text { of care } \\
\text { sessions }\end{array}$ & $\begin{array}{l}\text { \# of pregnant } \\
\text { women with } \\
\text { indicator }\end{array}$ \\
\hline 1 & 5 & 84 & 6 \\
\hline 2 & 0 & 55 & 0 \\
\hline 3 & 3 & 78 & 3,80 \\
\hline 4 & 28 & 143 & 19,60 \\
\hline 5 & 1 & 92 & 1,10 \\
\hline 6 & 5 & 54 & 9,30 \\
\hline 7 & 2 & 299 & 6,70 \\
\hline 8 & 12 & 40 & 30 \\
\hline 9 & 11 & 87 & 12,60 \\
\hline 10 & 12 & 98 & 12,20 \\
\hline 11 & 14 & 160 & 8,80 \\
\hline 12 & 7 & 109 & 6,40 \\
\hline Total & 100 & 1299 & 7,70 \\
\hline
\end{tabular}

\section{DISCUSSION}

Health promotion of pregnant women and their fetus should involve good prenatal care, which is considered one of the best indicators of obstetric and neonatal outcomes of pregnancy ${ }^{(5)}$. This care, 
considered as a priority in public health, aims at decreasing maternal/child morbidity and mortality ${ }^{(6)}$, and is characterized preventive and educational actions (frequent and planned contact of pregnant women with health services) and by the identification of risk situations for pregnant women and their fetus, with early and timely intervention in problems affecting pregnancy. The introduction of the prenatal care program, with the implementation of the Programa de Atenção Integral à Saúde da Mulher (Program for Comprehensive Health Care to Women - PAISM) in the 80's, brought about significant changes, such as the increase in coverage and in the average number of visits, as well as early start of prenatal follow-up ${ }^{(2)}$.

An increase in the number of prenatal appointments was observed in all but one BHU assessed, in the two periods studied. Although we do not have access to the number of inhabitants of each area covered by the units, a $58.8 \%$ increase in the number of pregnant women receiving prenatal care (818 in 2000, and 1299 in 2004) can be assumed, which is not a result of population growth alone (either the population as a whole or especially the number of women of fertile age); data obtained suggest greater accessibility of prenatal care.

According to the Ministry of Health, the ideal situation is to start prenatal follow-up in the first quarter of pregnancy and to have six or over appointments during pregnancy ${ }^{(4)}$. Comparing care in 2000 and 2004, we observed that 8 of the $12 \mathrm{BHU}$ assessed in 2004 presented an average of medical appointments below six, as well as a statistically significant decrease in the number of appointments performed in two units. Although the number of nursing appointments is very low in all BHU assessed, when the total number of appointments performed was considered (physicians + nurses) there was an increase in the ratio of pregnant women reaching the minimum amount of appointments recommended in half of the BHU. However, only $52.70 \%$ of the pregnant women seen in 2004 (685/1299) had reached this number of appointments and, at 3 units, the ratio of pregnant women with this indicator was lower than $50 \%$ (Table 1).

The higher number of prenatal visits and early care to pregnant women are associated with: greater intrauterine growth and lower rates of neonatal morbidity and mortality, preterm births, low birth weight and maternal deaths ${ }^{(7-11)}$. The beginning and end of follow-up is an important marker of prenatal quality, which should start ideally in the first timester of pregnancy and continue until the $3^{\text {rd }}$ trimester. Early start is important especially to decrease maternal morbidity and maintaining care until the $3^{\text {rd }}$ trimester favors identification of possible perinatal risks, enabling timely interventions. The ratio of pregnant women seen in the units assessed who started prenatal care in the first trimester of pregnancy increased in the studied period (Table 2), however, maintaining this care until the end of pregnancy, which was assessed by the number of pregnant women going to visits in the last trimester of pregnancy, was worse in 2004 when compared to 2000 . The increase in the proportion of early prenatal care may result from the number of pregnant women followed-up, as a whole, but the loss of follow-up until the end of pregnancy may be a consequence of lack of encouragement from the family, which is not aware of the benefits of followup. On the other hand, it can also be due to changes in the women's address, which is very common in this population. However, whatever the causes may be, loss of follow-up may lead to risk for motherschildren and actions are necessary to correct this problem.

A small number of prenatal visits results in missed opportunities to prevent disorders in pregnancy, especially infectious diseases ${ }^{(5)}$. Syphilis and HIV were the two infectious diseases used to assess quality in prenatal care in the present study. Although the Ministry of Health recommends two blood tests for Syphilis (VDRL) during prenatal follow-up and considers up to one case for 1,000 live births the goal to end congenital Syphilis, a study performed in 2004, with a sample representing pregnant women from 15 to 49 years old from all regions of the country, observed a prevalence rate of $1.6 \%$ for active Syphilis(12). The number of pregnant women with active Syphilis was estimated at 50,000 and the number of live births with congenital Syphilis at 12,000 (considering a $25 \%$ vertical transmission rate) in 2004, with a different prevalence in each region of the country, ranging from $1.9 \%$ in the Northeast to $1.3 \%$ in the Central-West ${ }^{(12)}$.

Although the ratio of units screening for Syphilis at least once increased from 2000 to 2004, the ratio of pregnant women with the two recommended tests continued very low $(3.60 \%$ to 
$69.20 \%$ ). Not identifying infected pregnant women leads to lack of treatment and impossibility to prevent the disease in newborns.

Early knowledge of HIV seropositivity in pregnancy enables prompt intervention, aiming to decrease the risk of transmitting the virus to infants. Prevalence of pregnant women with HIV in the units assessed was $3.70 \%$ in 2000 , decreasing to $0.60 \%$ in 2004. This decrease should not be seen as a decrease in the number of infected women in the city, which did not occur. Instead, it has to be considered that more tests were asked and that, in 2000, women who expressed some kind of "risk behavior" were the main group tested. Furthermore, there is a larger number of specialized centers in the city for care delivery to HIV+ pregnant women, which definitely decreased the search for prenatal care at the BHU. The rate found in 2004 is in agreement with the estimated prevalence of HIV-positive pregnant women, according to surveillance carried out in 2004 , which showed $0.537 \%$ prevalence for the Southeast ${ }^{(12)}$.

The increase in the number of pregnant women performing blood test for Syphilis and HIV at the BHU assessed suggest an effort to improve prenatal care quality, meeting the goals of the Prenatal and Birth Humanization Program and preventing vertical transmission of these infections. However, as previously seen ${ }^{(2)}$, the proportion of pregnant women performing the two tests for Syphilis at all units was much lower than that of women performing HIV tests.

Going back to the BHU after delivery is one prenatal care quality measures and a strategy that aims at preventing undesirable outcomes for mothers/ children. It is also a way of improving the relationship between client and service, turning the unit into a reference for health rather than for disease. Thus, it is expected that problems seen during labor can be followed-up, that the adherence of the family will be easier, and that the babies will be included in the health service. While there was no record of returns to the BHU in 2000, in 2004, this occurred at all units studied, although the return rate was above $50 \%$ in only four units. The introduction of family health programs may be responsible for this improvement.

The suggested excellence indicator of prenatal care $^{(2)}$ used the relationship between the number of pregnant women whose prenatal follow-up at the unit met the excellence-in-care criteria (starting prenatal follow-up in the first quarter, having at least six appointments; record of at least two screenings for Syphilis - VDRL and one blood test for HIV, and returning to the $\mathrm{BHU} 42$ within days after delivery) and the total number of pregnant women seen at this unit during the period. Its application to care performed in 2004 (Table 5) demonstrated that one of the units did not present care in accordance with this quality indicator, while care according to these criteria ranged from $1.10 \%$ to $30.0 \%$ at the other units. Considering that only $7.7 \%$ of the units assessed obtained care with this prenatal care quality indicator, there is an urgent need to improve care.

Also in Maringá (PR), a study conducted to assess prenatal care quality, using two different indicators (1998 to 2001), demonstrated $40 \%$ of inadequacy in care ${ }^{(13)}$. Another study assessing data from 555,979 women registered in SisPreNatal in the first two years after its introduction (2000 and 2001) demonstrated that only $20 \%$ of the women performed six prenatal visits, with twice as many requests for screenings to detect HIV infection than Syphilis; only $2 \%$ of the women registered in 2001, and 5\% in 2002 performed the set of activities proposed by the Ministry of Health ${ }^{(14)}$.

An important factor that may have interfered in prenatal care quality assessment is the poor quality of notes on women's medical chart. A study conducted at a BHU in Ribeirão Preto in 1995 demonstrated that prenatal care records are centered on "incomprehensibility" and "incompleteness"(15), which could lead to a "sub-record" of the data assessed.

Finally, we may say that prenatal care quality at the $12 \mathrm{BHU}$ studied improved: there was an increase in the number of pregnant women seen, and in the number of medical and nursing appointments performed; there was an increase in the search for care in the first trimester of the pregnancy and greater return of pregnant women to BHU in the postnatal period; there were also more screenings to identify pregnant women with positive Syphilis and HIV test results. However, continuation of follow-up until the end of pregnancy decreased in 2004, and only $7.70 \%$ of pregnant women received care that met all the activities established by the PHPN ${ }^{(2)}$ of the Ministry of Health, which had not been introduced in 2000. The low return rate to the $\mathrm{BHU}$ in the puerperal period may reflect the low level of connection between health professionals and pregnant women. 
Municipalization of health services seems to be important in this change, although we could not correlate it with the influence of the care model introduced (family health program, traditional health unit or mixed units). We should highlight, however, that difficulties found in assessing temporarily care in a certain region covered by the Family Health Program, since increase in the areas of coverage of a unit from the FHP results in a new identification number of homes and individuals, making it impossible to perform longitudinal follow-up of users of the service. The recent proposal by Penna and $\mathrm{col}^{(16)}$, who suggested collective prenatal consultations, could prioritize the principle of integrality and citizenship, favoring providing humane and total care to women.

\section{REFERENCES}

1. Tayra A. O sistema de Vigilância Epidemiológica de Sífilis Congênita no Estado de São Paulo, 1989 a 1997. [Dissertação] São Paulo (SP): Departamento de Epidemiologia, Faculdade de Saúde Publica USP; 2001.

2. Ministério da Saúde (BR). Programa de Humanização no Pré-natal e Nascimento: informações para gestores e técnicos. Brasília: Secretaria de Políticas de Saúde, Área Técnica da Saúde da Mulher; 2000.

3. Figueiredo EN. Qualidade da assistência no pré-natal pautada nos estudos das sífilis e sífilis congênita em unidades básicas de saúde do Município de São Paulo. [Tese] São Paulo (SP): Universidade Federal de São Paulo; 2004.

4. Ministério da Saúde (BR). Pré-natal e Puerpério: atenção qualificada e humanizada: Manual técnico. Brasília: Ministério da Saúde; 2005.

5. Amini SB, Catalana PM, Mann LI. Effect of prenatal care on obstetrical outcome. J Matern Fetal Med 1996; 5: 142-50.

6. Bergsjö $P$, Villar J. Scientific basis for the content of routine antenatal care. I. Philosophy, recent students, and power to eliminate or alleviate adverse maternal outcomes. Acta Obstet Gynecol Scand 1997; 76:1-14.

7. Bolzon DA, Guimarey L, Norry M. Factores de riesgo de retardo de crecimiento intrauterino y prematurez en dos municipios de la provincia de Buenos Aires. J Pediatr Rio de Janeiro 2000; 76(3):C8-14.

8. Kilsztajn S, Rossbach AC, Carmo MSN, Sugahara GTL. Assistência pré-natal, baixo peso e prematuridade no Estado de São Paulo, 2000. Rev Saude Publica 2003; 37(3):303-10.
9. Morais EN, Alflen TL, Spara P, Beitune PE. Momento e freqüência das visitas de pré-natal: repercussões sobre os nascimentos pré-termo. Rev Bras Ginecol Obstet 1988; $20: 25-32$

10. Petrou S, Kupek E, Vause S, Maresh M. Antenatal visits and adverse perinatal outcomes: results from a British population-based study. Eur J Obstet Gynecol Reprod Biol 2003; 106(1): 40-9

11. Vintzileos AM, Ananth CV, Smulian JC, Scorza WE, Knuppel RA. The impact of prenatal care on neonatal deaths in the presence and absence of antenatal high-risk conditions. Am J Obstet Gynecol 2002; 186(5):1011-6.

12. Ministério da Saúde (BR). Secretaria de Vigilância em Saúde. Programa Nacional de DST/Aids. Bol Epidemiol 2006; 3(1).

13. Nagahama EEI, Santiago SM. O cuidado pré-natal em hospital universitário: uma avaliação de processo. Cad Saúde Pública 2006; 22 (1): 173-9.

14. Serruya SJ, Cecatti JG, Lago TD. O Programa de Humanização no Pré-natal e Nascimento do Ministério da Saúde no Brasil: resultados iniciais. Cad. Saúde Pública 2004; 20(5):1281-9.

15. Oba MDV, Tavares MSG. A precariedade dos registros de assistência pré-natal em uma Unidade Básica de Saúde no Município de Ribeirão Preto. Rev. Latino-Am. Enfermagem 1998; 6 (1): 53-61.

16. Penna LHG, Carinhanha KI, Rodrigues RF. Consulta coletiva de pré-natal: uma nova proposta para uma assistência integral. Rev Latino-Am Enfermagem 2008; 16 (1): $158-60$ 